\title{
molecules
}

ISSN 1420-3049

(C) 2007 by MDPI

www.mdpi.org/molecules

Full Paper

\section{An Improved Synthesis of 4-Chlorocoumarin-3-sulfonyl Chloride and Its Reactions with Different Bidentate Nucleophiles to Give Pyrido[1',2':2,3]- and Thiazino[3',2':2,3]-1,2,4-Thiadiazino[6,5-c]Benzopyran-6-one 7,7-Dioxides}

Ahmed Jashari ${ }^{1, *}$, Evamarie Hey-Hawkins ${ }^{2}$, Bozhana Mikhova ${ }^{3}$, Gerald Draeger ${ }^{4}$ and Emil Popovski $^{5, *}$

${ }^{1}$ Group of Physics \& Chemistry, Faculty of Natural Sciences \& Mathematics, State University of Tetova, 1200 Tetova, Macedonia

${ }^{2}$ Faculty of Chemistry and Mineralogy, University of Leipzig, Johannsallee 29, D-04103 Leipzig, Germany; E-mail: hey@rz.uni-leipzig.de

3 Institute of Organic Chemistry with Centre of Phytochemistry, Bulgarian Academy of Sciences, Akad.G.Bonchev Str. Bl.9, Sofia 1113, Bulgaria

${ }^{4}$ Institute of Organic Chemistry, University of Hannover, D-30167, Hannover, Germany

${ }^{5}$ Institute of Chemistry, Faculty of Natural Sciences \& Mathematics, Ss. Cyril \& Methodius University, PO Box 162, 1000 Skopje, Macedonia

* Authors to whom correspondence should be addressed; E-mails: ahmed_alban@yahoo.com; emilp@iunona.pmf.ukim.edu.mk

Received: 3 June 2007; in revised form: 8 August 2007 / Accepted: 8 August 2007 / Published: 22 August 2007

Abstract: An improved synthetic method affording 4-chlorocoumarin-3-sulfonyl chloride (4) in very good yield (ca. $85 \%$ ) is reported. This compound was reacted with various bidentate nucleophiles such as 2-aminopyridines and 2-aminothiazoles in order to obtain substituted pyrido- and thiazino-1,2,4-thiadiazino-benzopyranone dioxides (potential anticancer and anti-HIV agents). These reactions occurred rapidly at room temperature giving yellowish precipitates, which are insoluble in common organic solvents, making the purification process challenging. Further investigation has shown that these fused heterocycles are not stable and decompose with opening of the 1,2,4-thiadiazine ring. 
Keywords: Synthesis, coumarin, 1,2,4-thiadiazines, fused heterocycles.

\section{Introduction}

Heterocyclic chemistry is one of the largest areas of research in organic chemistry and it is growing rapidly. Of all published organic chemistry literature, papers on heterocyclic synthesis accounted for around $60 \%$ in 1998 [1], but nowadays the fraction is much larger considering that novel heterocyclic compounds are published in different fields such as biochemistry, pharmaceuticals, materials and others. A similar trend is seen for coumarin, a heterocyclic system with a very large number of different derivatives. Coumarin is a compound with varied biological activities and in 1954 it was classified as a carcinogenic substance [2,3]. Main representatives of the class are its hydroxy derivatives 4-hydroxycoumarin (1) and 7-hydroxycoumarin (umbeliferone), also biologically active and very important for synthesis of other coumarin derivatives. Until now, an enormous number of compounds with coumarin systems in their structure have been synthesized. Those derivatives have shown a remarkably broad spectrum of pharmacological and physiological activities and they are used as anticoagulant [4-6], antibacterial [7,8], antiviral [9,10], antitumor [11-14], bactericidal [15], fungicidal [16], and anti-inflammatory agents [17]. Also, in recent times there are references to derivatives with anti-HIV activity [18-21].

On the other hand, the nitrogen and sulfur heterocyclic system families are very interesting because of their physicochemical properties with relevance to the design of new drugs and new materials, especially those relating to molecular conductors and magnets [22]. 1,2,4-Thiadizines are also used for treatment of HIV infection [23,24], as cardiovascular agents [25], for their antimicrobial effects [26], and as diuretics and antihypertensive drugs [27,28]. Based on these facts we wanted to combine the coumarinic system with 1,2,4-thiadiazines in the hope that the resulting novel heterocycles would be biologically active, especially as anticancer and anti-HIV agents. Also, we designated positions 3 and 4 of coumarin for annellation, because these positions are mainly attacked by electrophiles and nucleophiles, respectively [29].

\section{Results and Discussion}

Checchi et al. had previously reported one of the target compounds, pyrido[1',2':2,3]-1,2,4thiadiazino[6,5-c]benzopyran-6-one 7,7-dioxide (7a), as one of two possible structures [30]. It was obtained by reaction of 4-chlorocoumarin-3-sulfonyl chloride (4) with 2-aminopyridine (5a) in dry benzene. In our attempts to obtain the same compound 7a and its derivatives, unsatisfactory results were obtained and difficulties followed the synthesis of $\mathbf{4}$ as the key substrate. These problems were avoided by modification of the reaction route used, simplifying the preparation of the sodium salt $\mathbf{3}$ of 4-hydroxy-coumarin-3-sulfonic acid (2). Thus, considering that $\mathbf{2}$ is very soluble and stable in aqueous solution, $\mathbf{3}$ was obtained by simple mixing aqueous solutions of $\mathbf{2}$ and sodium chloride. Contrary to the abundant literature mentioning the good solubility of alkali-metal salts of sulfonic acids [31], the salts we prepared are not soluble in water and can be easily isolated in nearly quantitative yields from 
aqueous solutions by simple filtration (Scheme 1). Compound 3 was reported once by Huebner and Link [32], but the product was only characterized by its elemental analysis for sodium. This paper presents the full characterization of $\mathbf{3}$. In the next step $\mathbf{3}$ was chlorinated by refluxing with $\mathrm{POCl}_{3}$ for approximately three hours. Afterwards, instead of removing $\mathrm{POCl}_{3}$ by vacuum distillation, the suspension was poured onto a mixture of crushed ice and water to afford a nice precipitate of $\mathbf{4}$ in 85 \% yield (lit. [30]: ca. $25 \%$ ) (Scheme 2). Modification of this step was based on the report that the chlorine atom at position 4 cannot be attacked by water [29]. Also, it was found that in general the sulfonyl chlorides are insoluble and stable in water [31].

\section{Scheme 1}<smiles>O=c1cc(O)c2ccccc2o1</smiles>

1

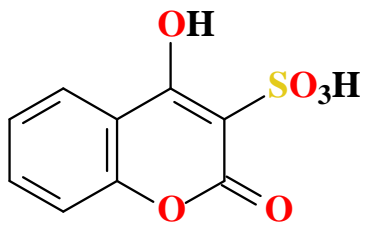

2<smiles>O=c1oc2ccccc2c(O)c1S(=O)(=O)O</smiles>

3

Structural assignment of 4 was based on ${ }^{1} \mathrm{H}$ - and ${ }^{13} \mathrm{C}-\mathrm{NMR}$, IR and MS spectral analysis. The signals of four aromatic protons at 7.34-7.85 ppm could be observed in the ${ }^{1} \mathrm{H}-\mathrm{NMR}$ spectrum, as well as nine signals in the expected regions of the ${ }^{13} \mathrm{C}-\mathrm{NMR}$ spectrum. In the mass spectrum (ESI, +ve mode) there was a peak at $\mathrm{m} / \mathrm{z} 302$ corresponding to the $[\mathrm{M}+\mathrm{Na}]^{+}$species. These data confirmed that the product isolated from water is identical with that isolated by vacuum distillation. Substrate $\mathbf{4}$ is very soluble in organic solvents and it was used without further purification.

\section{Scheme 2}

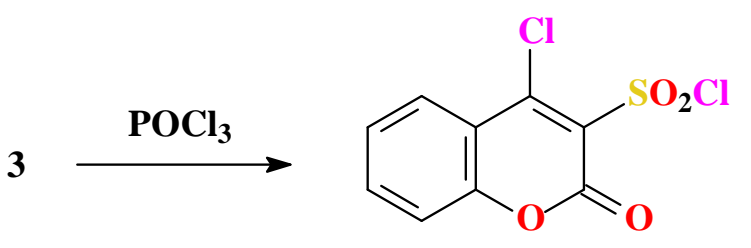

4

$85 \%$ crude yield

Reactions of $\mathbf{4}$ with 2-aminopyridines $\mathbf{5 a - h}$ and 2-aminothiazoles $\mathbf{6 a}, \mathbf{b}$ were performed in acetonitrile as a polar and aprotic solvent. Reactions were very fast at room temperature and after a few minutes crude yellowish precipitates of 7a-f and 8a,b were formed, respectively (Scheme 3).

Using single crystal X-ray diffraction the structure of 7a has been determined and the dilemma about its configuration was eliminated (Figure 1). The compound crystallizes in monoclinic space group P21/n with cell dimensions $a=16.3541(5) \AA, b=9.2246(2) \AA, c=16.7064(5) \AA, \alpha=90.00^{\circ}$, $\beta=110.802(4)^{\circ}, \gamma=90.00^{\circ}, V=2356.04(11) \AA^{3}, Z=8$ [33]. All atoms in the molecule are in one plane, except for the two oxygen atoms of the $\mathrm{SO}_{2}$ group, which are arranged symmetrically out of plane. 


\section{Scheme 3}

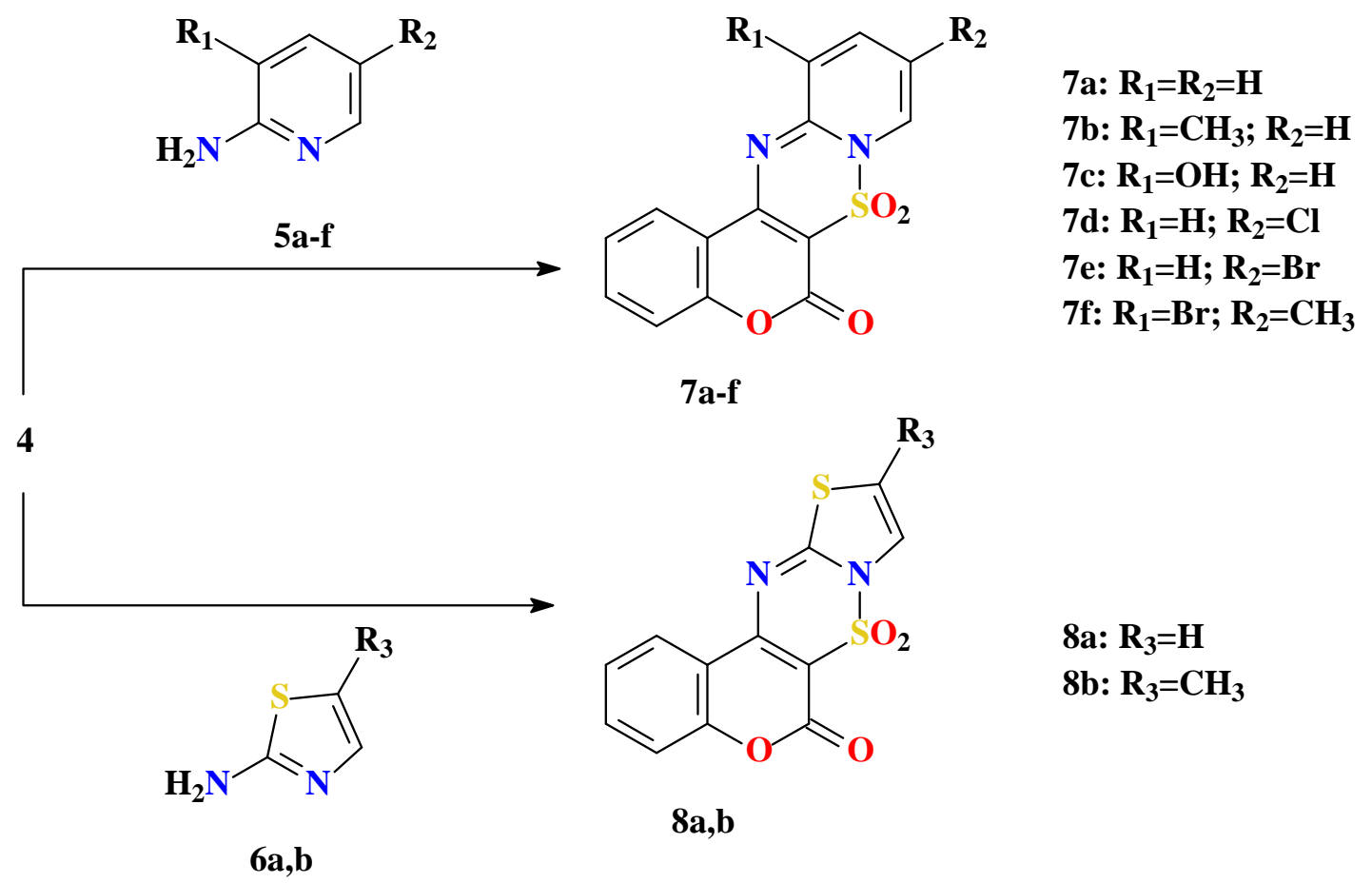

Figure 1. Diagram of compound 7a with the crystallographic numbering system.

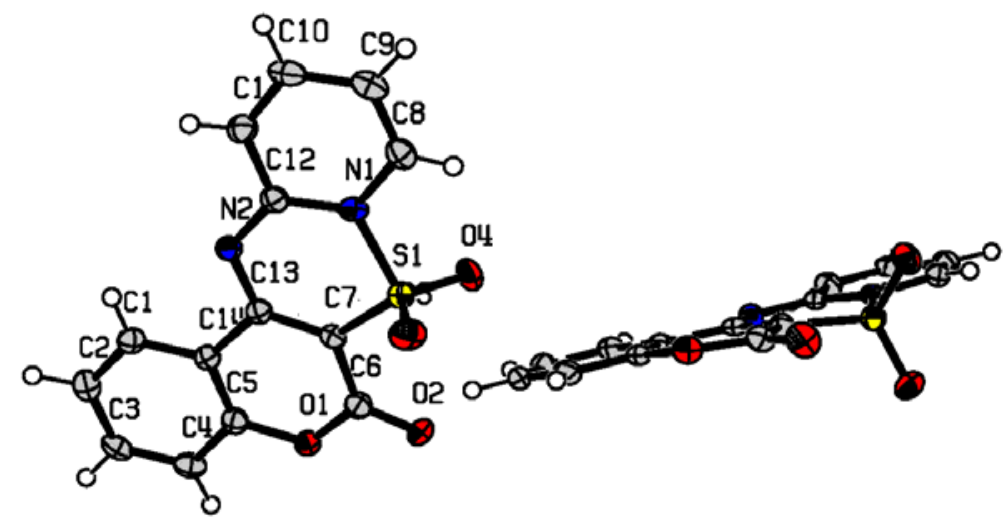

All products 7a-f and $\mathbf{8 a}, \mathbf{b}$ are very insoluble in common organic solvents, with the exception of DMSO, which caused difficulties when purifying them. Purifications were performed on chromatographic columns with slow gradient elution using dry solvents. Further investigation confirmed that compounds 7a-f and 8a,b are not stable. Analysis carried out on $\mathbf{7 d}$ proved that those systems annulated on coumarin decompose with opening of the 1,2,4-thiadiazine ring. Decomposition in the solid state was slow, but when crystals were dissolved in DMSO, where complete elimination of traces of water is not possible, decomposition was rapid (within a few hours). Therefore, it was assumed that these heterocycles are sensitive to moisture. The reaction with water releases sulfuric acid. Since the decomposition is slow in the beginning it is possible that the reaction is autocatalytic, so when the amount of sulfuric acid increases decomposition is more rapid (Scheme 4). 


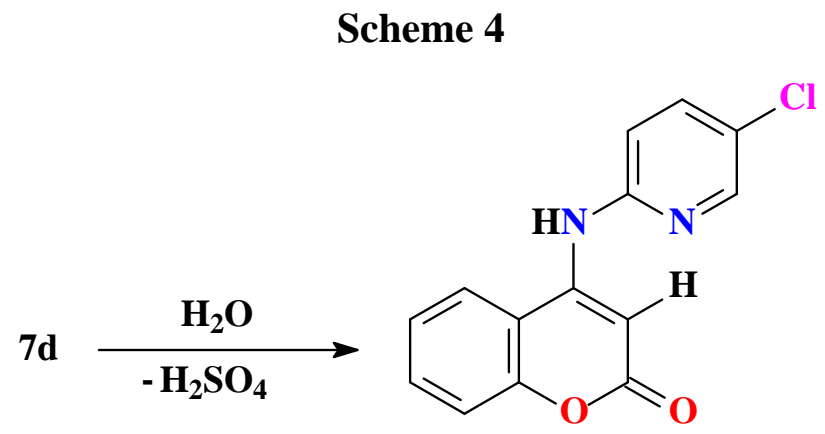

9

4-(5-Chloropyridin-2-yl-amino)-benzopyran-2-one (9) was isolated in pure form as white crystals after decomposition of $\mathbf{7 d}$. In the IR spectrum one sharp band at $3328 \mathrm{~cm}^{-1}$, corresponding to an $\mathrm{NH}$ vibrational mode and a $\mathrm{C}=\mathrm{O}$ band at $1672 \mathrm{~cm}^{-1}$, which is evidently lower than the band of the annulated heterocycles at $1710 \mathrm{~cm}^{-1}$, were noticed. The ${ }^{1} \mathrm{H}$-NMR spectrum showed a singlet at $9.5 \mathrm{ppm}$ corresponding to the $\mathrm{NH}$ proton, seven aromatic protons ranging from 7.4 to $7.9 \mathrm{ppm}$ and one singlet at $7.3 \mathrm{ppm}$, corresponding to the proton at the 3-position of the coumarin ring. In the ${ }^{13} \mathrm{C}-\mathrm{NMR}$ spectrum there were 14 signals, as expected, and confirming our assumptions the signal of the coumarin ring C-3 at $92.8 \mathrm{ppm}$ is a doublet. Finally, in the mass spectrum signals at $\mathrm{m} / \mathrm{z} 273$ (ESI pos) for the $[\mathrm{M}+\mathrm{H}]^{+}$species and $\mathrm{m} / \mathrm{z} 272(\mathrm{EI})$, corresponding to the molecular peak $[\mathrm{M}]^{+}$, were noticed.

\section{Scheme 5}

10a: $\mathbf{R}_{4}=\mathrm{NO}_{2} ; \mathbf{R}_{5}=\mathbf{R}_{6}=\mathrm{H}$ 10b: $\mathrm{R}_{4}=\mathrm{CH}_{3} ; \mathrm{R}_{5}=\mathrm{NO}_{2} ; \mathrm{R}_{6}=\mathrm{H}$ 10c: $\mathbf{R}_{4}=\mathrm{R}_{5}=\mathrm{H} ; \mathrm{R}_{6}=\mathrm{NO}_{2}$

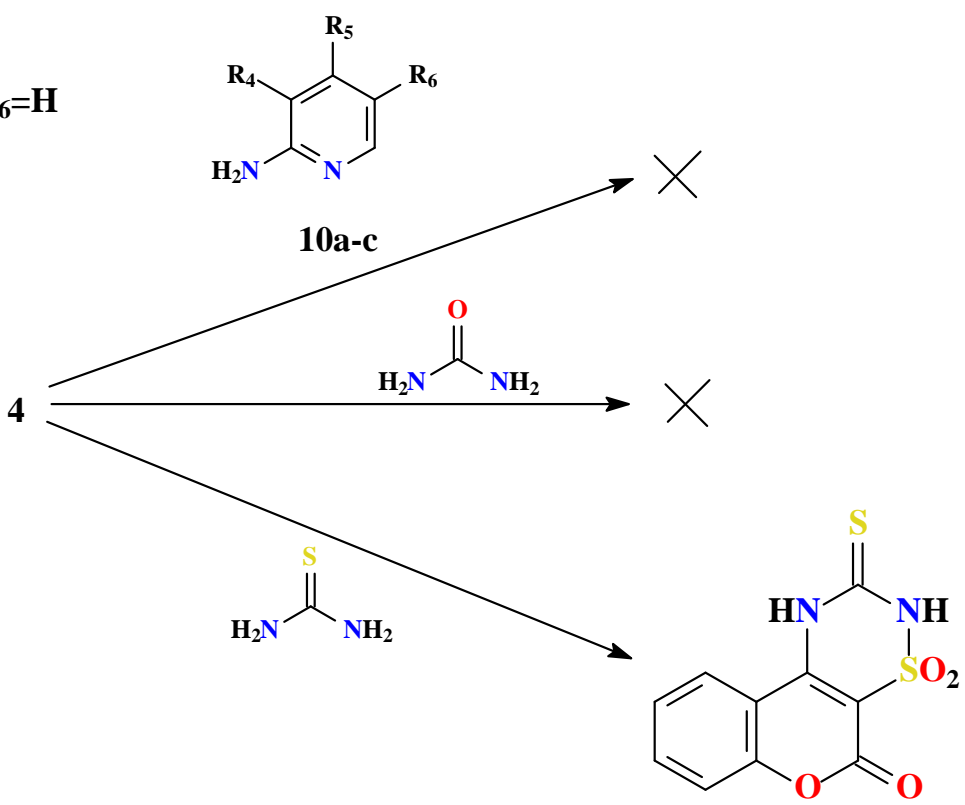

11

It was also observed that the substituent in the 2-aminopyridine moiety is very important because of its influence on the reaction, rate and the stability of derivatives. Substrate $\mathbf{4}$ did not react with any 2-aminopyridines possessing a nitro group in positions 3, 4 or 5 (10a-c, Scheme 5). This is understandable considering that the nitro group has a strongly negative inductive effect $(-I)$, as well as a negative resonance effect $(-M)$. As a result of both effects, the electron density on the nitrogen atoms 
is much lower, which consequently weakens the nucleophilicity [34]. In view of these facts it was concluded that weak bidentate nucleophiles cannot substitute the chlorine atoms in $\mathbf{4}$, to form a 1,2,4thiadiazine ring, and that only strong nucleophiles are able to do so. To prove this, comparative reactions of $\mathbf{4}$ were performed with urea as a weaker and thiourea as a stronger bidentate nuclophile. A yellowish precipitate of $8 H, 10 H-1,2,4$-thiadiazino[6,5-c]benzopyran-9-thioxo-6-one 7,7-dioxide (11, Scheme 5) was formed within a few minutes after mixing an acetonitrile solution of $\mathbf{4}$ and thiourea crystals at room temperature, while all attempts to obtain a product from the reaction with urea failed.

\section{Experimental}

\section{General}

Melting points were determined on a Reichert heating plate and are uncorrected. C, $\mathrm{H}$ elemental analysis was carried out on a Coleman Model 33 carbon-hydrogen analyzer. $\mathrm{N}$ elemental analysis was carried out by the Dümas method. NMR spectra were recorded on a Bruker $400 \mathrm{MHz}$ instrument using DMSO- $d_{6}$ as solvent and tetramethylsilane as internal standard. Infrared spectra (KBr pellets) were measured on a Perkin-Elmer System 2000 FT IR. ESI-TOF mass spectra were measured using an LCT mass spectrometer (Waters) equipped with a lockspray dual-electrospray ion source combined with Waters Alliance 2695 HPLC unit. The X-ray structure of 7a was measured on a CCD Xcalibur S diffractometer. All non-hydrogen atoms were refined anisotropically and all hydrogen atoms were placed in ideal positions. All the reagents and solvents were obtained from commercial sources and were used without further purification. 4-Hydroxycoumarin-3-sulfonic acid (2) was synthesized following a literature method [30, 35], as described below in more detail.

\section{Synthesis of 4-hydroxycoumarin-3-sulfonic acid (2)}

Monochlorosulfonic acid $\left(\mathrm{HSO}_{3} \mathrm{Cl}, 8 \mathrm{~mL}\right.$ ) was added dropwise to dry dioxane (85 $\left.\mathrm{mL}\right)$. When the temperature of the solution reached $50{ }^{\circ} \mathrm{C}$ 4-hydroxycoumarin (1, $10 \mathrm{~g}, 0.062 \mathrm{~mol}$ ) was added in one portion. After short vigorous mixing a very voluminous yellowish precipitate formed from the bright yellow solution. This precipitate was filtered on a glass funnel and washed first with dioxane (20 $\mathrm{mL})$ and then with ether ( 2 x $20 \mathrm{~mL}$ ). After washing we obtained a white powder (92\% yield), with m.p. 98-100 ${ }^{\circ} \mathrm{C}$ (lit. [34] $92{ }^{\circ} \mathrm{C}$ ). White crystals were obtained after recrystallization from acetone. Anal. Calc. for $\mathrm{C}_{9} \mathrm{H}_{6} \mathrm{O}_{6} \mathrm{~S}$ (242.20): 44.63\% C, $2.50 \% \mathrm{H}$; found $44.58 \% \mathrm{C}, 2.47 \% \mathrm{H}$; IR (KBr, cm $\left.{ }^{-1}\right)$ : $3400-$ 2500 (both $\mathrm{OH}$, stretching vibrations, very broad, indicating hydrogen bonding), 1705 (CO), 1326 ( $\mathrm{SO}_{2}$, antisymmetric vibrations), 1157 ( $\mathrm{SO}_{2}$, symmetric vibrations), 1621, 1608 and 1556 (aromatic vibrations); ${ }^{1} \mathrm{H}-\mathrm{NMR} \delta$ : 14.1 (br s, 2H, OH), 7.87 (d, 1H, 5-ArH), 7.67 (t, 1H, 7-ArH) and 7.33-7.36 (m, 2H, 6- and 8-ArH); ${ }^{13} \mathrm{C}-\mathrm{NMR} \delta: 162.42,157.10,152.68,133.66,124.46,124.29,116.32,114.93$ and 107.68; MS (ESI neg) m/z: $241[\mathrm{M}-\mathrm{H}]^{-}$. 
Synthesis of sodium 4-hydroxycoumarin-3-sulfonate (3)

4-Hydroxycoumarin-3-sulfonic acid (2, $10 \mathrm{~g}, 0.041 \mathrm{~mol})$ was dissolved in a small quantity of water and with vigorous mixing a saturated aqueous solution of sodium chloride (35 g NaCl/100 mL) was added. The rapidly formed white precipitate was filtered on a Buchner funnel and washed with cold water. Recrystallization from acetonitrile gave a white solid (98\% yield) with m.p. > 300. Anal. Calc. for $\mathrm{C}_{9} \mathrm{H}_{5} \mathrm{NaO}_{6} \mathrm{~S}$ (264.18): 40.92\% C, 1.91\% H; found 40.18\% C, 1.27\% H; IR (KBr, cm ${ }^{-1}$ ): 3614-2500 $\left(\mathrm{OH}\right.$, stretching vibrations, very broad, indicating hydrogen bonding), $1713(\mathrm{CO}), 1329\left(\mathrm{SO}_{2}\right.$, antisymmetric vibrations), 1147 ( $\mathrm{SO}_{2}$, symmetric vibrations), 1623, 1610 and 1563 (aromatic vibrations); ${ }^{1} \mathrm{H}-\mathrm{NMR} \delta$ : 13.9 (br s, H, OH), 7.88 (d, 1H, 5-ArH), 7.68 (t, 1H, 7-ArH) and 7.36-7.40 (m, 2H, 6- and 8-ArH); ${ }^{13} \mathrm{C}-\mathrm{NMR} \delta$ : 162.36, 157.38, 152.51, 133.64, 124.34, 124.27, 116.26, 114.77 and 107.48; MS (ESI pos) $m / z: 287[\mathrm{M}+\mathrm{Na}]^{+}$.

Synthesis of 4-chlorocoumarin-3-sulfonyl chloride (4)

Compound 3 (10 g, $0.036 \mathrm{~mol}$ ) was mixed with $\mathrm{POCl}_{3}(50 \mathrm{~mL})$. The resulting suspension was refluxed for approx. 3 hours, then cooled to room temperature and slowly poured onto crushed ice mixed with water. The yellowish solid formed was collected by filtration, washed with ice-water and recrystallized from cyclohexane. Yield $85 \%$; m.p. 148-150 ${ }^{\circ} \mathrm{C}$; Anal. Calc. for $\mathrm{C}_{9} \mathrm{H}_{4} \mathrm{Cl}_{2} \mathrm{O}_{4} \mathrm{~S}$ (279.09): 38.73\% C, 1.44\% H; found 38.07\% C, 1.12\% H; IR (KBr, $\mathrm{cm}^{-1}$ ): 3465 (CO, overtone), 1752 and 1742 (CO), 1300 ( $\mathrm{SO}_{2}$, antisymmetric vibrations), 1173 ( $\mathrm{SO}_{2}$, symmetric vibrations), 1601, 1587 and 1516 (aromatic vibrations); ${ }^{1} \mathrm{H}-\mathrm{NMR} \delta$ : 7.85 (d, 1H, 5-ArH), 7.67 (t, 1H, 7-ArH) and 7.34-7.40 (m, 2H, 6and 8-ArH); ${ }^{13} \mathrm{C}-\mathrm{NMR} \delta$ : 162.15, 157.48, 150.9, 133.97, 125.92, 125.43, 116.33, 114.58 and 110.45; MS (ESI pos) $\mathrm{m} / \mathrm{z}: 302[\mathrm{M}+\mathrm{Na}]^{+}$.

General procedure for preparation of substituted pyrido[1',2':2,3]-1,2,4-thiadiazino[6,5-c] benzo-pyran-6-one 7,7-dioxides 7a-f and thiazolo[3',2':2,3]-1,2,4-thiadiazino[6,5-c] benzopyran-6-one 7,7-dioxides 8a,b

Compound 4 ( $1 \mathrm{~g}$, $3.6 \mathrm{mmol}$ ) was dissolved in acetonitrile $(25 \mathrm{~mL})$. To this solution was added the base (5a-f, 6a,b) in equimolar ratio and the mixture was stirred with a magnetic stirrer at room temperature for approx. 1 hour. The reaction was followed by TLC, usually using as eluent an 80:20 mixture of toluene/ethanol. A yellowish precipitate was formed, which was collected on a Buchner funnel. The precipitate was washed with a small amount of acetonitrile and dried in a dessicator. This precipitate was applied to a chromatographic column filled with silica gel 60 and it was eluted with a 100:0, 90:10, 80:20 and 70:30 gradient of toluene/ethanol. The main fraction was evaporated on a rotovapor and the crystals were collected and analyzed.

Pyrido[1',2':2,3]-1,2,4-thiadiazino[6,5-c]benzopyran-6-one 7,7-dioxide (7a). Yellow crystals recrystallized from ethyl acetate. Yield 89 \%; m.p. 228-230 ${ }^{\circ} \mathrm{C}$ (lit. [30] 226-228 ${ }^{\circ} \mathrm{C}$ ); Anal. Calc. for $\mathrm{C}_{14} \mathrm{H}_{8} \mathrm{~N}_{2} \mathrm{O}_{4} \mathrm{~S}$ (300.29): 56.00\% C, 2.69\% H, 9.33\% N; found 55.26\% C, $1.93 \% \mathrm{H}, 8.79 \% \mathrm{~N}$; IR (KBr, $\mathrm{cm}^{-1}$ ): 3435 (CO, overtone), 1710 (CO), 1352 ( $\mathrm{SO}_{2}$, antisymmetric vibrations), 1158 ( $\mathrm{SO}_{2}$, symmetric 
vibrations), 1633, 1609 and 1554 (aromatic vibrations); ${ }^{1} \mathrm{H}-\mathrm{NMR} \delta$ : 8.85 (d, 1H, 8-ArH), 8.35 (d, 1H, 1-ArH), 8.14 (t, 1H, 10-ArH) 7.75 (t, 1H, 3-ArH), 7.59 (d, 1H, 11-ArH) and 7.40-7.46 (m, 3H, 2-, 4and 9-ArH); ${ }^{13} \mathrm{C}-\mathrm{NMR} \delta$ : 161.63, 153.50, 153.20, 148.23, 146.57, 138.99, 132.20, 123.72, 123.03, 118.62, 117.13, 115.40, 114.74 and 92.55; MS (ESI pos) m/z: $301[\mathrm{M}+\mathrm{H}]^{+}, 364\left[\mathrm{M}+\mathrm{Na}+\mathrm{CH}_{3} \mathrm{CN}\right]^{+}$, $623[2 \mathrm{M}+\mathrm{Na}]^{+}$.

11-Methylpyrido[1',2':2,3]-1,2,4-thiadiazino[6,5-c]benzopyran-6-one 7,7-dioxide (7b). Yellow crystals recrystallized from ethanol. Yield $90 \%$; m.p. 198-200 ${ }^{\circ} \mathrm{C}$; Anal. Calc. for $\mathrm{C}_{15} \mathrm{H}_{10} \mathrm{~N}_{2} \mathrm{O}_{4} \mathrm{~S}$ (314.32): 57.32\% C, 3.21\% H, 8.91\% N; found 57.12\% C, 3.09\% H, 8.19\% N; IR (KBr, $\left.\mathrm{cm}^{-1}\right): 3401$ (CO, overtone), 3092 (ArH), 2924 ( $\mathrm{CH}_{3}$, antisymmetric), $2853\left(\mathrm{CH}_{3}\right.$, symmetric), 1710 (CO), 1359 ( $\mathrm{SO}_{2}$, antisymmetric vibrations), 1155 ( $\mathrm{SO}_{2}$, symmetric vibrations), 1626, 1610 and 1568 (aromatic vibrations); ${ }^{1} \mathrm{H}-\mathrm{NMR} \delta$ : 8.72 (d, 1H, 8-ArH), 8.39 (d, 1H, 1-ArH), 8.05 (d, 1H, 10-ArH), 7.74 (t, 1H, 3-ArH), 7.40-7.45 (m, 2H, 2- and 4-ArH), 7.33 (t, 1H, 9-ArH) and 2.52 (s, 3H, $\left.\mathrm{CH}_{3}\right)$; ${ }^{13} \mathrm{C}-\mathrm{NMR} \delta$ : $155.10,153.74,153.21,151.83,141.68,134.63,134.47,126.02,125.65,124.93,117.44,117.33$, 116.97, 97.60 and 17.60;

11-Hydroxypyrido[1',2':2,3]-1,2,4-thiadiazino[6,5-c]benzopyran-6-one 7,7-dioxide (7c). Yellow crystals purified by recrystallization from DMF. Yield $78 \%$; m.p. $>300{ }^{\circ} \mathrm{C}$ (dec); Anal. Calc. for $\mathrm{C}_{14} \mathrm{H}_{8} \mathrm{~N}_{2} \mathrm{O}_{5} \mathrm{~S}$ (316.29): 53.16\% C, 2.55\% H, 8.86\% N; found 52.81\% C, $1.93 \% \mathrm{H}, 8.71 \% \mathrm{~N}$; IR (KBr, $\mathrm{cm}^{-1}$ ): 3429-2650 (OH), 1716 (CO), 1353 ( $\mathrm{SO}_{2}$, antisymmetric vibrations), 1156 ( $\mathrm{SO}_{2}$, symmetric vibrations), 1660, 1611 and 1571 (aromatic vibrations); ${ }^{1} \mathrm{H}-\mathrm{NMR} \delta$ : 10.06 (s, 1H, OH), 8.89 (d, 1H, 8ArH), 8.33 (d, 1H, 1-ArH), 7.71 (t, 1H, 3-ArH), 7.46 (d, 1H, 10-ArH) 7.34-7.48 (m, 2H, 2- and 4-ArH) and $7.27(\mathrm{t}, 1 \mathrm{H}, 9-\mathrm{ArH})$; Because of the very low solubility it was not possible to record the corresponding ${ }^{13} \mathrm{C}-\mathrm{NMR}$ spectra.

9-Chloropyrido[1',2':2,3]-1,2,4-thiadiazino[6,5-c]benzopyran-6-one 7,7-dioxide (7d). Yellow crystals recrystallized from ethanol. Yield 65 \%; m.p. > $300{ }^{\circ} \mathrm{C}$ (dec); Anal. Calc. for $\mathrm{C}_{14} \mathrm{H}_{7} \mathrm{ClN}_{2} \mathrm{O}_{4} \mathrm{~S}$ (334.73): 50.24\% C, 2.11\% H, 8.37\% N; found 50.12\% C, 1.98\% H, 7.89\% N; IR (KBr, $\left.\mathrm{cm}^{-1}\right): 3080$ (ArH), 1715 (CO), 1345 ( $\mathrm{SO}_{2}$, antisymmetric vibrations), 1161 ( $\mathrm{SO}_{2}$, symmetric vibrations), 1620, 1609 and 1547 (aromatic vibrations); ${ }^{1} \mathrm{H}-\mathrm{NMR} \delta$ : 8.95 (s, 1H, 8-ArH), 8.37 (d, 1H, 1-ArH), 8.24 (d, 1H, 10-ArH), 7.72 (t, 1H, 3-ArH), 7.50 (d, 1H, 11-ArH) and 7.39-7.48 (m, 2H, 2- and 4-ArH); ${ }^{13} \mathrm{C}-$ NMR $\delta$ : 161.52, 153.89, 153.15, 147.99, 147.52, 140.60, 132.27, 123.46, 123.04, 117.15, 116.64, $115.43,114.27$ and 92.61.

9-Bromopyrido[1',2':2,3]-1,2,4-thiadiazino[6,5-c] benzopyran-6-one 7,7-dioxide (7e). Yellow crystals recrystallized from benzene. Yield 69 \%; m.p. > $300{ }^{\circ} \mathrm{C}$ (dec); Anal. Calc. for $\mathrm{C}_{14} \mathrm{H}_{7} \mathrm{BrN}_{2} \mathrm{O}_{4} \mathrm{~S}$ (379.18): 44.35\% C, $1.86 \% \mathrm{H}, 7.39 \% \mathrm{~N}$; found $45.69 \% \mathrm{C}, 2.08 \% \mathrm{H}, 6.98 \% \mathrm{~N}$; IR $\left(\mathrm{KBr}, \mathrm{cm}^{-1}\right): 3440(\mathrm{CO}$, overtone), 3074 ( $\mathrm{ArH}), 1712$ (CO), 1344 ( $\mathrm{SO}_{2}$, antisymmetric vibrations), 1161 ( $\mathrm{SO}_{2}$, symmetric vibrations), 1672, 1608 and 1593 (aromatic vibrations); ${ }^{1} \mathrm{H}-\mathrm{NMR} \delta$ : 9.10 (s, 1H, 8-ArH), 8.39 (d, 1H, 1-ArH), 8.27 (d, 1H, 10-ArH), 7.79 (t, 1H, 3-ArH), 7.56 (d, 1H, 11-ArH) and 7.46-7.52 (m, 2H, 2- and 4-ArH); ${ }^{13} \mathrm{C}-\mathrm{NMR} \delta$ : 161.52, 153.99, 153.10, 148.21, 147.54, 140.62, 132.17, 123.66, 122.94, 117.15, 116.85, 115.41, 114.59 and 92.62. 
9-Methyl-11-bromopyrido[1',2':2,3]-1,2,4-thiadiazino[6,5-c]benzopyran-6-one 7,7-dioxide (7f). Yellow crystals recrystallized from ethanol. Yield $72 \%$; m.p. $>300{ }^{\circ} \mathrm{C}$ (dec); Anal. Calc. for $\mathrm{C}_{15} \mathrm{H}_{9} \mathrm{BrN}_{2} \mathrm{O}_{4} \mathrm{~S}$ (393.21): 45.82\% C, 2.31\% H, 7.12\% N; found 45.61\% C, 2.12\% H, 6.99\% N; IR $\left(\mathrm{KBr}, \mathrm{cm}^{-1}\right)$ : 3429 (CO, overtone), 3101 (ArH), $2962\left(\mathrm{CH}_{3}\right.$, stretching), 1717 (CO), $1345\left(\mathrm{SO}_{2}\right.$, antisymmetric vibrations), 1153 ( $\mathrm{SO}_{2}$, symmetric vibrations), 1645, 1610 and 1546 (aromatic vibrations); ${ }^{1} \mathrm{H}-\mathrm{NMR} \delta$ : 8.78 (s, 1H, 8-ArH), 8.55 (s, 1H, 10-ArH), 8.44 (d, 1H, 1-ArH), 7.81 (t, 1H, 3$\mathrm{ArH}$ ), 7.45-7.52 (m, 2H, 2- and 4-ArH) and 2.2 (s, 3H, $\left.\mathrm{CH}_{3}\right) ;{ }^{13} \mathrm{C}-\mathrm{NMR} \delta: 161.50,153.85,153.17$, 148.29, 148.0154, 141.51, 132.23, 123.69, 122.43, 117.14, 116.96, 115.31, 114.29, 92.60 and 12.05.

Thiazolo[3',2':2,3]-1,2,4-thiadiazino[6,5-c] benzopyran-6-one 7,7-dioxide (8a). Yellowish crystals recrystallized from methanol. Yield $68 \%$; m.p. $>300{ }^{\circ} \mathrm{C}$ (dec); Anal. Calc. for $\mathrm{C}_{12} \mathrm{H}_{6} \mathrm{~N}_{2} \mathrm{O}_{4} \mathrm{~S}_{2}(306.31$ ): 47.05\% C, 1.97\% H, 9.15\% N; found 46.68\% C, 1.93\% H, 8.72\% N; IR (KBr, cm ${ }^{-1}$ ): 1707 (CO), 1321 ( $\mathrm{SO}_{2}$, antisymmetric vibrations), 1154 ( $\mathrm{SO}_{2}$, symmetric vibrations), 1627, 1612 and 1568 (aromatic vibrations); ${ }^{1} \mathrm{H}-\mathrm{NMR} \delta$ : 8.36 (d, 1H, 8-ArH), 8.30 (d, 1H, 1-ArH), 7.79 (t, 1H, 3-ArH), 7.63 (d, 1H, 9$\mathrm{ArH})$ and 7.43-7.50 (m, 2H, 2- and 4-ArH); ${ }^{13} \mathrm{C}-\mathrm{NMR} \delta: 169.14,156.22,154.38,153.63,135.42$, 126.75, 126.28, 125.58, 122.18, 117.46, 116.82 and 115.09; MS (ESI pos) m/z: $307[\mathrm{M}+\mathrm{H}]^{+}, 370$ $\left[\mathrm{M}+\mathrm{Na}+\mathrm{CH}_{3} \mathrm{CN}\right]^{+}$and $635[2 \mathrm{M}+\mathrm{Na}]^{+}$; (EI) $\mathrm{m} / \mathrm{z}: 306[\mathrm{M}]^{+}$and $242\left[\mathrm{M}-\mathrm{SO}_{2}\right]^{+}$.

9-Methylthiazolo[3',2':2,3]-1,2,4-thiadiazino[6,5-c]benzopyran-6-one 7,7-dioxide (8b). Yellowish crystals recrystallized from acetonitrile. Yield $71 \%$ m.p. $240-245{ }^{\circ} \mathrm{C}$ (dec); Anal. Calc. for $\mathrm{C}_{13} \mathrm{H}_{8} \mathrm{~N}_{2} \mathrm{O}_{4} \mathrm{~S}_{2}$ (320.34): 48.74\% C, 2.52\% H, 8.74\% N; found 48.11\% C, 2.20\% H, 8.34\% N; IR (KBr, $\mathrm{cm}^{-1}$ ): 1709 (CO), 1323 ( $\mathrm{SO}_{2}$, antisymmetric vibrations), 1156 ( $\mathrm{SO}_{2}$, symmetric vibrations), 1625, 1612 and 1569 (aromatic vibrations); ${ }^{1} \mathrm{H}-\mathrm{NMR} \delta$ : 8.28 (d, 1H, 8-ArH), 8.17 (d, 1H, 1-ArH), 7.79 (t, $1 \mathrm{H}, 3-\mathrm{ArH})$, 7.43-7.49 (m, 2H, 2- and 4-ArH) and 2.20 (s, 3H, $\left.\mathrm{CH}_{3}\right) ;{ }^{13} \mathrm{C}-\mathrm{NMR} \delta: 169.16,153.92$, 153.23, 135.06, 126.90, 126.37, 125.25, 122.33, 119.84, 117.95, 117.10, 113.46 and 11.75; MS (ESI pos) $\mathrm{m} / \mathrm{z}: 321[\mathrm{M}+\mathrm{H}]^{+}, 384\left[\mathrm{M}+\mathrm{Na}+\mathrm{CH}_{3} \mathrm{CN}\right]^{+}$and $663[2 \mathrm{M}+\mathrm{Na}]^{+}$; (EI) $\mathrm{m} / \mathrm{z}: 320[\mathrm{M}]^{+}$and $256[\mathrm{M}-$ $\left.\mathrm{SO}_{2}\right]^{+}$.

4-(5-Chloropyridin-2-ylamino)-benzopyran-2-one (9). This compound was obtained as white crystals after two recrystallizations of 7d from ethanol; m.p. $>300{ }^{\circ} \mathrm{C}$ (dec); Anal. Calc. for $\mathrm{C}_{14} \mathrm{H}_{9} \mathrm{ClN}_{2} \mathrm{O}_{2}$ (272.69): $61.66 \%$ C, $3.33 \% \mathrm{H}, 10.27 \% \mathrm{~N}$; found $61.01 \% \mathrm{C}, 2.98 \% \mathrm{H}, 9.85 \% \mathrm{~N}$; IR (KBr, cm $\left.{ }^{-1}\right): 3328$ (NH), 1672 (CO), 1626, 1614 and 1561 (aromatic vibrations); ${ }^{1} \mathrm{H}-\mathrm{NMR} \delta$ : 9.53 (s, $1 \mathrm{H}, \mathrm{NH}$ ), 8.43 (s, 1H, 6-PyH), 8.31 (d, 1H, 4-PyH), 7.89 (d, 1H, 5-CumH), 7.65 (t, 1H, 7-CumH), 7.36-7.50 (m, 3H, 6CumH, 8-CumH and 3-PyH) and 7.34 (s, 1H, 3-CumH); ${ }^{13} \mathrm{C}-\mathrm{NMR} \delta: 161.96,153.49,152.96,148.21$, 145.79, 138.35, 132.54, 124.99, 124.03, 123.26, 117.54, 116.73, 114.97 and 92.87; MS (ESI pos) m/z: $273[\mathrm{M}+\mathrm{H}]^{+}$; (EI) $\mathrm{m} / \mathrm{z}: 272[\mathrm{M}]^{+}$and $244[\mathrm{M}-\mathrm{CO}]^{+}$.

8H,10H-1,2,4-thiadiazino[6,5-c]benzopyran-9-thioxo-6-one 7,7-dioxide (11). Yellowish crystals purified with column chromatography. Yield $49.5 \%$; m.p. $278-280{ }^{\circ} \mathrm{C}$ (dec); Anal. Calc. for $\mathrm{C}_{10} \mathrm{H}_{6} \mathrm{~N}_{2} \mathrm{O}_{4} \mathrm{~S}_{2}$ (282.29): 42.55\% C, 2.14\% H, 9.92\% N; found 42.12\% C, 1.96\% H, 9.08\% N; IR (KBr, $\left.\mathrm{cm}^{-1}\right)$ : $3206(\mathrm{NH}), 3027(\mathrm{NH}), 1720(\mathrm{CO}), 1416\left(\mathrm{SO}_{2}\right.$, antisymmetric vibrations), $1187\left(\mathrm{SO}_{2}\right.$, symmetric vibrations); ${ }^{1} \mathrm{H}-\mathrm{NMR} \delta$ : 9.27 (br s, 2H, NH); 7.75-7.90 (m, 2H, ArH); 7.49 (m, 2H, ArH). 
${ }^{13} \mathrm{C}-\mathrm{NMR} \delta$ : 167.33; 155.79; 153.20; 152.07; 135.43; 125.95; 124.82; 117.78; 117.58; 115.54; MS (EI) $\mathrm{m} / \mathrm{z}: 282[\mathrm{M}]^{+}$.

\section{Acknowledgements}

We are grateful to Deutscher Akademischer Austausch Dienst (DAAD) for financial support. We also appreciate the technical support and hospitality from the Faculty of Chemistry and Mineralogy at the University of Leipzig, especially to the PhD student Jens Baldamus at the same Faculty who helped with the crystal structure determination.

\section{References and Notes}

1. Gupta, R. R.; Kumar, M.; Gupta, V. Heterocyclic Chemistry; Springer-Verlag: Berlin, 1998.

2. Fed. Reg. 191239 (Mar. 5, 1954).

3. Sax N. I. Dangerous Properties of Industrial Materials (4th Ed.); Van Nostrand Co.: New York, 1975.

4. Manolov, I.; Danchev, N.D. Synthesis, toxicological and pharmacological assessment of some 4hydroxycoumarins. Eur. J. Med. Chem. Chim. Ther. 1995, 30, 531-536.

5. Arora, R. B.; Mathur, C. N. Relationship between structure and anticoagulant activity of coumarin derivatives. Brit. J. Pharmacol. 1963, 20, 29-35.

6. Ziegler, E.; Rossmann, U. Chemistry of 4-hydroxycoumarins. VIII. Synthesis of anticoagulants. Monatsh. Chem. 1957, 88, 25-34.

7. Al-Haiza, M. A.; Mostafa, M. S.; El-Kady, M. Y. Synthesis and Biological Evaluation of Some New Coumarin Derivatives. Molecules 2003, 8, 275-286.

8. Dutton, C. J.; Sutcliffe, J.; Yang, B. 4-Hydroxy coumarin derivatives with antibacterial activity. PCT Int. Appl. US1993/006308, 1994.

9. $\quad$ Parmar, V. S.; Bisht, K. S.; Jain, R.; Singh, S.; Sharma, S. K.; Gupta, S.; Malhotra, S.; Tyagi, O. D.; Vardhan, A.; Pati, H. N.; Berghe, D. V.; Vlietinck, A. J. Synthesis, Antimicrobial and Antiviral Activities of Novel Polyphenolic Compounds. Ind. J. Chem. Sec. B, 1996, 35, 220-232.

10. Ishikawa, T.; Kotake, K.I.; Ishii, H. Synthesis of Toddacoumaquinone, a Coumarin-Naphthoquinone Dimer, and Its Antiviral Activities. Chem. Pharm. Bull. 1995, 43, 1039-1041.

11. Nofal, Z. M.; El-Zahar, M. I.; Abd El-Karim, S. S. Novel Coumarin Derivatives with Expected Biological Activity, Molecules 2000, 5, 99-113.

12. Raev, L.; Voinova, E.; Ivanov, I.; Popov, D. Antitumor activity of some coumarin derivatives. Pharmazie 1990, 45, 696-702 [Chem. Abstr. 1990, 114, 74711 B].

13. Valenti, P.; Rampa, A.; Recanatini, M.; Bisi, A.; Belluti, F.; Da Re, P.; Carrara, M.; Cima, L. Synthesis, cytotoxicity and SAR of simple geiparvarin analogues. Anticancer Drug Des. 1997, 12, 443-451.

14. Shah, A.; Naliapara, Y.; Sureja, D.; Motohashi, N.; Kawase, M.; Miskolci, C.; Szabo, D.; Molnar, J. 6,12-Dihydro-1-Benzopyrano[3,4-b][1,4]Benzothiazin-6-ones Synthesis and MDR Reversal in Tumor Cells, Anticancer Res. 1998, 18, 3001-3004. 
15. El-Sayed, A. M.; Abd-Allah, O. A. Synthetic and Biological Studies on Coumarin Hydrazone Derivatives. Phosporus, Sulfur Silicon Relat. Elem. 2001, 170, 75-86.

16. El-Agrody, A. M.; Abd El-Latif, M. S.; El-Hady, N. A.; Fakery, A. H.; Bedair, A. H. Heteroaromatization with 4-hydroxycoumarin. Part II. Molecules 2001, 6, 519-527.

17. Emmanuel-Giota, A. A.; Fylaktakidou, K. C.; Hadjipavlou-Litina, D. J.; Litinas, K. E.; Nicolaides, D. N. Synthesis and biological evaluation of several 3-(coumarin-4-yl)tetrahydroisoxazole and 3-(coumarin-4-yl)-dihydropyrazole derivatives. J. Heterocycl. Chem. 2001, 38, 717-722.

18. Spino, C.; Dodier, M.; Sotheeswaran, S. Anti-HIV Coumarins from Calophyllum Seed Oil. Bioorg. Med. Chem. Lett. 1998, 8, 3475-3478.

19. Thaisrivongs, S.; Watenpaugh, K. D.; Howe, W. J.; Tomich, P. K.; Dolak, L. A.; Chong, K.-T.; Tomich, C.-S. C.; Tomasselli, A. G.; Turner, S. R.; Strohbach, J. W.; Mulichak, A. M.; Janakiraman, M. N.; Moon, J. B.; Lynn, J. C.; Horng, M.-M.; Hinshaw, R. R.; Curry, K. A.; Rothrock, D. J. Structure-Based Design of Novel HIV Protease Inhibitors: CarboxamideContaining 4-Hydroxycoumarins and 4-Hydroxy-2-pyrones as Potent Nonpeptidic Inhibitors. $J$. Med. Chem. 1995, 38, 3624-3637.

20. Gaddam, S.; Khilevich, A.; Filer. C.; Rizzo, J. D.; Giltner, J.; Flavin, M. T.; Xu, Z. Q. Synthesis of Dual C-14-Labeled (+)-Calanolide-A, a Naturally-Occurring Anti-HIV Agent. J. Label. Comp. Radiopharm. 1997, 39, 901-906.

21. Zhao, H.; Neamati, N.; Hong, H.; Mazumder, A.; Wang, S.; Sunder, S.; Milner, G. W. A.; Pommier, Y.; Burke, Jr., T. R. Coumarin-Based Inhibitors of HIV Integrase. J. Med. Chem. 1997, 40, 242-249.

22. García-Valverde, M.; Tomás, T. Sulfur-Nitrogen Heterocycles, Molecules 2005, 10, 318-320.

23. Vega, S.; Diaz, J. A.; Arranz, E. Thieno- and pyrazolo-1,2,4-thiadiazino-1,1-dioxides with antiHIV activity. ES2136013, 1999.

24. Arranz, M. E.; Diaz, J. A.; Ingate, S. T.; Witvrouw, M.; Pannecouque, C.; Balzarini, J.; De Clerq, E.; Vega, S. Synthesis and anti-HIV activity of 1,1,3-trioxo-2H,4H-thieno[3,4-e][1,2,4]thiadiazines (TTDs): a new family of HIV-1 specific non-nucleozide reversetranscriptase inhibitors. Bioorg. Med. Chem. 1999, 7, 2811-2822.

25. Vega, S.; Arranz, M. E. 4H-Thieno[3,4-e]- and 4H-pyrazolo[4,3-e]-1,2,4-thiadiazine 1,1-dioxides. Synthesis, chemical properties and evaluation of their potential cardiovascular activity. $J$. Heterocycl. Chem. 2004, 41, 45-50.

26. Di Bella, M.; Monzani, A.; Andrisano, M. G.; Fabio, U.;Quaglio, G. P. Antimicrobial effect of derivatives of 1,2,4-benzothiadiazine-1,1-dioxide. Part VII. Ediz. Scient. 1979, 34, 81-88.

27. Robertson, D. W.; Steinberg, M. I. Potassium channel modulators: scientific applications and therapeutic promise. J. Med. Chem. 1990, 33, 1529-1541.

28. Longman, S. D; Hamilton, T. C. Potassium channel activator drugs: mechanism of action, pharmacological properties, and therapeutical potential. Med. Res. Rev. 1992, 12, 73-148.

29. Tabakovic, K.; Tabakovic, I.; Trkovnik, M.; Trinajstic, N. Chemistry of Coumarin.-Nucleophilic Substitutions of 4-Chloro-3-nitrocoumarin with Hard and Soft Nucleophiles, Liebigs Ann. Chem. 1983, 11, 1901-1909. 
30. Checchi, S.; Pecori, V. L.; Bambagiotti, A. M. 4-Hydroxycoumarins. VII. Reactivity of 4-chloroand 4-hydroxycoumarin-3-sulfonyl chlorides. Gazz. Chim. Ital. 1967, 97, 1749-1761.

31. Vogel, A. I. Vogel's Text-book of Practical Organic Chemistry, $5^{\text {th }}$ ed.; Longman: London, 1989, pp. 873-874; pp. 874-878.

32. Huebner, C. F.; Link, K. P. Studies on 4-hydroxycoumarin. VII. Reactions of 4-hydroxycoumarin with cationoid reagents. J. Am. Chem. Soc. 1945, 67, 99-102.

33. CCDC 646550 contains the supplementary crystallographic data for this paper. These data can be obtained free of charge via www.ccdc.cam.ac.uk/data_request/cif, or by emailing data_request@ccdc.cam.ac.uk, or by contacting The Cambridge Crystallographic Data Centre, 12, Union Road, Cambridge CB2 1EZ, UK; fax: +44 1223336033.

34. Smith, M. B. March's Advanced Organic Chemistry; Reactions, Mechanism and Structure, $5^{\text {th }}$ ed.; John Wiley \& Sons, Inc.: New York, 2001; pp. 363-364.

35. Kovác, M.; Sabatié, A.; Floch, L. Synthesis of coumarin sulfonamides and sulfonylurea. ARKIVOC 2001, 100-108.

Sample Availability: Samples of compounds 2, 3, 4, 7a-f, 8a,b, 9 and 11 are available from the authors.

(C) 2007 by MDPI (http://www.mdpi.org). Reproduction is permitted for noncommercial purposes. 